\title{
dossier
}

\section{Bartolomé María de las Heras, un obispo entre dos cuchillos}

\author{
Carlos Zegarra MoretTi \\ Universidad de Bonn (Bonn, Alemania) \\ carlos.zegarra.moretti@gmail.com
}

Código ORCID: 0000-0003-4641-1940

\section{RESUMEN}

Se propone estudiar el rol de los obispos durante la ejecución de las reformas borbónicas de la segunda mitad del siglo XVIII en América. Para el caso peruano, la historiografía se ha centrado únicamente en los mitrados considerados con el epíteto de «obispos ilustrados» y que, en algunos casos, han servido para ser considerados colaboradores de los planes regalistas de la administración borbónica. Esta postura eclipsa la propia agenda de estos prelados y las posturas contrarias a la política regalista. Guiado bajo el desempeño de Bartolomé María de las Heras en su gobierno episcopal de Cusco, se mostrará cómo estableció un frente para combatir las medidas regias que cada vez amenazaban con mayor fuerza los privilegios que la Iglesia había gozado desde su implantación en suelo americano. 
Palabras clave: Bartolomé María de las Heras, derecho canónico indiano, obispos peruanos, regalismo borbónico, Cusco

\title{
Bartolomé María de las Heras, a bishop between two knives
}

\begin{abstract}
This article aims to study the role of bishops during the execution of the Bourbon reforms of the second half of the 18th century in America. In the Peruvian case, the historiography has focused only on prelates considered with the epithet of «enlightened bishops» and that, in some cases, have served to be considered collaborators of the regalist plans of the Bourbon administration. This position overshadows the own agenda of these prelates and the positions contrary to the royalist policy. Guided under the performance of Bartolomé María de las Heras in his episcopal government of Cusco, it will be shown how he established a front to combat the royal measures that increasingly threatened the privileges that the Church had enjoyed since its implantation on American soil.
\end{abstract}

Keywords: Bartolomé María de las Heras, canon law, Perwian bishops, Bourbon regalism, Cusco

\section{INTRODUCCIÓN}

LAS REFORMAS BORBÓNICAS EMPRENDIDAS a lo largo de la segunda mitad del siglo XVIII por la Corona española afectaron, también, al poder eclesiástico asentado en América. Si bien de estas medidas la expulsión de los miembros de la Compañía de Jesús de los territorios controlados por España ha sido la más fértil en discusiones y análisis, no fue la única llevada a cabo. Dentro del conjunto de reformas eclesiásticas, tema poco estudiado sistemáticamente en el ámbito andino, se encuentran, entre otras medidas: la secularización de las doctrinas a cargo de órdenes religiosas (Andrien, 2009; 
Aguirre, 2008), la intervención de la inquisición (Peralta Ruiz, 1999), el manejo de los cabildos eclesiásticos con la reducción hasta un tercio de la presencia criolla por la real cédula de 1776 (Ganster, 1986, p. 148), el control fiscal sobre los diezmos (Jaramillo, 2014, p. 309), el afianzamiento de los vales reales (Gayol, 2007, p. 76). Asimismo, integraron la política de la reforma clerical de Carlos III, otras disposiciones particulares destinadas a limitar la independencia de los foros eclesiásticos (Brading, 1994, pp. 142-149).

Para emprender tal política, el régimen virreinal puso en marcha al entramado burocrático, donde los representantes del vicepatronato (virreyes, regentes de audiencia e intendentes) jugaron una pieza clave. ${ }^{1}$ De la misma manera, se ha precisado que los mitrados desempeñaron un papel resaltante como colaboradores. Al igual que los funcionarios reales, los altos miembros de la curia tuvieron el mismo objetivo, convirtiéndose, siguiendo las palabras de Rosas Lauro (2009, p. 148), en «clérigos administradores» al servicio de la monarquía borbónica. No obstante, este esquema interpretativo no permite examinar la sempiterna tensión entre las autoridades de ambos bandos por cuestiones de jurisdicción ni las posturas contrarias a las políticas dieciochescas que pudieron adoptar los obispos. Lo anterior conduce a las siguientes preguntas: ¿tuvieron los representantes de las diócesis americanas interés en defender los privilegios eclesiásticos? y, en ese caso, ¿qué formas, estrategias y mecanismos decidieron utilizar?

Para responder a lo anterior, tomo como caso de estudio un gobierno episcopal en específico. Bartolomé María de las Heras ha recibido notoriedad entre los peruanistas por su actuación diplomática durante la transición al sistema republicano. Con menor interés se ha mirado su administración eclesiástica previa. En Cusco, el nacido en Andalucía desarrolló, como explicaré, una puntual, sutil

1 Sobre el cargo de vicepatronatos en la creación del sistema de intendencias véase, para el caso de Nueva España, Pietschmann (1996, pp. 167-168). 
y bien preparada defensa contra la política regalista. Para su elaboración, empleó el apoyo profesional de su grupo cercano de colaboradores, cuyo conocimiento en derecho civil y canónico el prelado había incentivado.

Sugiero en las siguientes páginas la necesidad de disponer de otro modelo para entender la compleja relación de los obispos americanos con las reformas dieciochescas. Si bien fueron colaboradores, tuvieron margen para aplicar campañas, amparadas en el derecho canónico indiano, para intentar frenar la disminución de los privilegios que gozaban. Si bien los niveles de éxito fueron mínimos, nos muestra una cara desconocida de las reacciones a la política borbónica eclesiástica. Para mostrar lo anterior baso mi exposición en los siguientes apartados: una propuesta de perfil de los obispos peruanos en la segunda mitad del siglo XVIII en base a su vinculación a los planes borbónicos; una breve reconstrucción de la administración cusqueña del obispo Las Heras; la formación de un frente letrado por medio de la Universidad San Antonio Abad y las instituciones judiciales; $y$, por último, la ofensiva canónica en ocasión de la real cédula de 27 de abril de 1784 .

\section{Obispos entre la ILUSTRACión y el REgalismo}

Varios mitrados americanos de las últimas décadas del siglo XVIII han sido considerados representantes de la ilustración católica (De la Puente Candamo, 2012, p. 192; Macera, 1997; Rosas Lauro, 2009; Guibovich, 2014, p. 17; Vizuete Mendoza, 2014). Para el caso del actual territorio peruano, tal denominación se ha aplicado principalmente a Baltasar Jaime Martínez Compañón (obispo de Trujillo entre 1779 y 1790) y Pedro José Chávez de la Rosa (obispo de Arequipa, 1788-1804). ¿Qué rasgos han hecho que reciban tal epíteto por la historiografía?

Fueron personajes que se mostraron interesados por áreas del saber que excedían sus tradicionales obligaciones pastorales. Se 
preocuparon por tener un contacto cercano con la realidad local, tanto en lo social y cultural como en lo económico-productivo. Esta postura tenía el aparente objetivo de la aplicación de medidas para fomentar el «desarrollo» de la población por medio de la educación, la salud y su inserción en la economía. Lo anterior se manifestó durante la realización de visitas pastorales, en la reforma de los planes educativos en instituciones eclesiásticas (seminarios y escuelas de letras) y en el contacto con la cultura impresa. Esta postura se entrelazaba con los diferentes intereses de la Corona borbónica que incluían una centralización del poder, el aumento de los ingresos fiscales, así como la regulación de las relaciones de grupos sociales (por medio de, por ejemplo, la «Pragmática Sanción sobre matrimonio de 1776»).

En virtud de lo anterior, las llamadas «visitas-reformas» (Rosas Lauro, 2009, p. 157) tenían el fin de emprender medidas para la disciplina de los eclesiásticos, regular la vida de la población por medio de los sacramentos y esclarecer las finanzas de las iglesias locales. Así, las inspecciones itinerantes ocuparon parte de las actividades de los obispos. En ese sentido, Chávez de la Rosa emprendió la suya apenas iniciado su gobierno episcopal, de la cual se conoce únicamente su preocupación moral y educativa del clero (Chambers, 2003, p. 142). Mayores estudios ha despertado el recorrido del obispo norteño. Entre 1780 y 1785, Martínez Compañón inauguró su visita empezando por las instituciones centrales hasta las doctrinas periféricas. En el último caso dirigió a los curas un cuestionario con interrogantes pastorales y aspectos sociales, culturales y productivos sobre su colación encargada. Con ello se buscaba recopilar información para incentivar «la industria y comercio» (Restrepo, 2012, pp. 202-205).

Junto a los planes productivos, el incentivo de la educación caracteriza la labor de las dignidades episcopales dieciochescas en sintonía con su época. De esta manera, es recurrente encontrar menciones sobre la fundación de escuelas de primeras letras y la restructuración del plan de estudios de los seminarios. Así, dentro 
del ajuar que trasladó el obispo Pedro José a su sede mistiana se encontraron catecismos y devocionarios, que sumaban dieciséis cajones, destinados, según el funcionario aduanero, para «los párvulos y escuelas de Arequipa» (Guibovich, 2014, p. 28). De la misma manera, el mitrado gaditano realizó una reforma en el Seminario San Jerónimo tanto en el nivel arquitectónico como en el educativo. En el último punto propuso a la Corona hispana el establecimiento de cátedras de derecho civil, canónico, natural y de gentes. Para expresar con claridad y detalle su propuesta a las autoridades supremas presentó, en 1802, un estatuto, conocido como Constituciones del Seminario de Arequipa (Reales Cédulas, 1808, pp. 25-188). El proyecto, salvo la cátedra de gentes, de tendencia liberal, fue aceptado por los funcionarios en España (Vargas Ugarte, 1961, pp. 317-318), aunque no se ha medido con certeza su impacto.

Por su parte, durante el decenio episcopal de Martínez Compañón se realizó un sinnúmero de fundaciones de escuelas. Las informaciones hacen referencia a que estos establecimientos de instrucción básica superaron el centenar, con programas específicos para la población indígena y las mujeres (Restrepo, 2012, pp. 207-208; Macera, 1997, p. 37). El seminario conciliar tampoco estuvo ajeno al obispo navarro. Luego de ejecutar proyectos infraestructurales y la elaboración de estatutos, se volvió a abrir en febrero de 1792. Entre las nueve cátedras, se incluyó la de historia eclesiástica y de derecho canónico. Aún no se conocen el contenido ni los libros empleados en estos cursos ni sus maestros, salvo que se utilizaron las obras de Kempis y Luis de Granada como inspiración espiritual (Restrepo, 1992, pp. 325-344). A pesar de la mención de la asignatura de derecho canónico, esta no fue incluida — ni la de historia eclesiásticaen la Guía de Unanue, un documento de carácter oficial publicado a lo largo de la última década del siglo (Unanue, 1793, p. 282; 1797, p. 227). La no mención puede atribuirse a la falta de aprobación real del nuevo plan de estudios, lo cual no impidió que de manera interna se haya impartido. 
Otra fuente que ha servido para mostrar la vinculación de los obispos con la corriente intelectual de la época ha sido los inventarios de sus bibliotecas personales. La perteneciente a Martínez Compañón superó los dos millares a su arribo a Trujillo (Soule, 2014), pero no se ha dado a conocer en su totalidad. ${ }^{2}$ Debido a lo anterior, me centro en la de Chávez de la Rosa. La compilación impresa de la dignidad arequipeña, compuesta por 1,497 volúmenes al momento de su llegada a costas peruanas (Guibovich, 2014, p. 23), albergó títulos del nuevo pensamiento en convivencia con las tendencias de la época previa. Las de contenido político reflejarían, según Guibovich (2014, p. 29), «la sintonía de Chávez de la Rosa con la política religiosa de Carlos III», poseyendo, así, textos escritos por o sobre el obispo regalista, Juan de Palafox y Mendoza, entre otros.

Además de la temática anterior, es necesario resaltar la presencia de títulos jurídicos, tanto de recopilación legislativa hispánica e indiana, aunque sea mínima (Guibovich, 2014, p. 26). Más escasa, aunque sumamente valiosa, es la referida al derecho canónico. En el corpus podemos encontrar concilios (aunque ninguno americano), las obras clásicas de Villarroel y de Frasso sobre el patronato en Indias (Guibovich, 2014, pp. 54, 126). Mención especial se dirige a dos obras: la Instituta canónica del jurista italiano Lorenzo Selvagio, publicada en 1770, y la Jus ecclesiasticum universum del jansenista Bernardo Van Spen (Guibovich, 2014, pp. 55, 126; Peralta Ruiz, 1999, pp. 189, 200), quienes eran los autores autorizados por el Consejo de Indias para la enseñanza del derecho canónico en América (Salinas, 2000, p. 222). ${ }^{3}$ A ellos también se suma Carlos Sebastiano Berardi

2 El análisis presentado por Soule no incluye títulos legales (Soule, 2014, pp. 21 24). Se dispone de otro estudio de la biblioteca por Restrepo, publicado en 1993 , pero no he podido tener acceso a dicho material.

3 José Toribio Rodríguez de Mendoza, rector del Convictorio San Carlos (Lima), defendió y fundamentó, en 1794 y 1795, el uso de la obra de Selvagio como material de enseñanza de instituciones eclesiásticas, dentro del derecho canónico, en el centro educativo a su cargo (Vargas Ugarte, 1970, pp. 16, 22, 52, 63-67, 
(Guibovich, 2014, p. 114), de referencia en la formación canonista (Yauzi, 2002, p. 1867; Terráneo, 2017, p. 127).

Además de las labores de estos obispos en su función pastoral, tuvieron obligaciones hacia el poder civil, que consistió principalmente en no poner oposición a las decisiones de los burócratas reales. Por ejercicio del especial patronato indiano (Hera, 1970; Fisher, 2000, pp. 83-95), el monarca español influía decididamente en la elección de las supremas autoridades eclesiásticas, por lo que procuraba elegir a aliados. Debido en parte a lo anterior, a varios de estos eclesiásticos de la época borbónica se les ha considerado «clérigos administradores» por contribuir decisivamente a implementar los planes reformistas de la Corona española (Rosas Lauro, 2009, p. 148; Fisher, 2000, p. 93; Restrepo, 2012, p. 199). Mitrados como Martínez Compañón y Chávez de la Rosa reflejan, en palabras de Rosas Lauro, el cambio de timonel hacia «el imperialismo borbónico», que se caracterizaría principalmente en la «búsqueda de canales de financiamiento en el siglo XVIII» (Rosas Lauro, 2009, p. 148). Si bien no faltaron enfrentamientos por la jurisdicción entre los obispos y las autoridades locales — sobre todo con los intendentes-, no tenían raíces profundas que cuestionaran los preceptos regalistas. ${ }^{4}$

Según el esbozo arriba presentado de los obispos americanos, de quienes se resalta la comunión en cierta manera con el pensamiento y proceder característicos de la época y el apoyo a las ideas y planes regalistas, ¿es posible extenderlo a otros compañeros del

115). Parece que no llegó a introducirse en el claustro carolino, prevaleciendo la obra de Berardi (Vargas Ugarte, 1970, p. 126).

4 Para Arequipa, el obispo Chávez de la Rosa se enfrentó con el intendente Álvarez por la designación de curatos vacantes (Croix, 1859, pp. 66-68), véase, también, Chambers (2003, p. 152). En cuanto al caso de Trujillo, véase Restrepo (1992, pp. 238-239). Vargas Ugarte desarrolla algunos casos de conflicto social entre virreyes y prelados. Por ejemplo, las fuertes discrepancias entre el virrey Superunda y el arzobispo de Lima Barroeta por formalidades e intereses personales (Vargas Ugarte, 1961, pp. 127-131), tensión igualmente reflejada en Estenssoro (1992, pp. 184-185) y Huarcaya (2018). 
suelo peruano? Basado en el esquema presentado, someto a análisis a un gobierno episcopal contemporáneo a los ya mentados.

\section{El obispo Bartolomé María de las Heras (1790-1806)}

Natural de Carmona, en Andalucía, Bartolomé María de las Heras vino al mundo el 24 de abril de 1743 (Mendiburu, 1880, pp. 254-255). Compaginó la carrera eclesiástica con los estudios jurídicos graduándose de abogado (Unanue, 1793, p. 232). En España logró posicionarse en la corte, siendo capellán de honor del rey, años después no dudaría en utilizar estos vínculos estrechos con estos influyentes personajes. Antes de recibir la consagración episcopal en Perú, adquirió experiencia en cabildos catedralicios sudamericanos. Llegó a Huamanga en marzo de 1786 en calidad de deán, pero por un intenso enfrentamiento con su obispo, Francisco López Sánchez, que parecía no tener solución, las autoridades regias decidieron reubicar al andaluz en otra sede. ${ }^{5}$ Recibió en diciembre de 1787 el deanato de La Paz, para cuyo traslado la Corona se mostró interesada en financiar por medio del virrey Croix. En agosto de 1789 seguía en tal cargo, de ubicación cercana a su próximo destino. ${ }^{6}$

El curso ascendente de Las Heras en tierras peruanas no se detuvo. Fue consagrado obispo de Cusco y, seguidamente, arzobispo de Lima. Su labor como representante máximo de la Iglesia peruana ante San Martín ha ocupado largamente a los especialistas, entre otros: De la Puente Candamo (1948, pp. 178-180), Vargas Ugarte

5 La figura del obispo huamanguino merece ser estudiada con más detenimiento para entender la recepción del regalismo y vicepatronazgo y su influencia en la formación de alianzas locales. Además de los conflictos internos, López Sánchez protagonizó enfrentamientos con el cabildo civil y el intendente Manrique (Fisher, 2000, p. 89).

6 Archivo General de Indias [AGI], Lima, 1578; AGI, Lima, 686, N. 28; AGI, Lima, 683, F. 5v-6r. 
(1962), Nieto Vélez (1972) y Morán (2012). Situación opuesta sucede con los más de quince años previos a su traslado a la capital virreinal (Vargas Ugarte, 1961, pp. 255-258). ․ Entre 1790 y 1806, Bartolomé estuvo en Cusco, cuya labor bien puede encajar con el perfil de los obispos que apoyaron los principios ilustrados.

El obispo Las Heras llegó a Cusco en los últimos meses de 1790 tras su designación por Carlos IV y su consagración a orillas del río Chili por Chávez de la Rosa el 12 de octubre del mismo año (Vargas Ugarte, 1961, p. 256). Como sus pares en Arequipa y Trujillo, una de sus primeras acciones fue la ejecución de visitas pastorales. ${ }^{8}$ Siguiendo a Vargas Ugarte (1961, p. 256), el obispo realizó un total de cuatro visitas, iniciando el 28 de abril de 1792 en Checacupe y terminando el 11 de noviembre de 1795 en Urubamba. Estas las realizó por sí mismo junto a la compañía del experimentado José Gallegos en el cargo de secretario de visita. ${ }^{9}$ En base a registros parroquiales, se puede reconstruir con cierto detalle el itinerario. Algunas evidencias de su ruta son: 1 de mayo de 1792 en San Pedro de Cacha (partido de Tinta), agosto en Ayaviri (partido de Lampa), y noviembre y diciembre nuevamente en Tinta. Tras esta primera etapa remitió un informe al virrey Francisco Gil de Taboada, quien, en marzo de 1793, alabó el avance en la reforma clerical (García-Abásolo, 2015, p. 55). Otra comitiva itinerante realizada por el binomio Las Heras y Gallegos sucedió en 1794. Así, en julio inspeccionaron los templos de Tungasuca y Surimana (Tinta), lo mismo en Capacmarca (Chumbivilcas) en noviembre del mismo año. ${ }^{10}$

7 Vargas Ugarte describió a Las Heras como un infatigable «perfecto prelado», resaltando principalmente sus visitas pastorales (Vargas Ugarte, 1961, p. 256).

8 Para una rápida revisión de las visitas pastorales en la diócesis del Cusco en el siglo XVIII, véase Zegarra Moretti (2015, pp. 419-427).

9 Gallegos había sido visitador comisionado en tiempos del obispo Juan Manuel Moscoso y Peralta (Zegarra Moretti, 2015, p. 427).

10 Estos datos han sido extraídos de Zegarra Moretti (2012b, pp. 240, 262, 297, 301, 309, 313, 348, 469, 517). 
En la última gira, el obispo adelantó una circular como preparativo al encuentro, que incluía aspectos sobre la administración de bienes parroquiales (Vargas Ugarte, 1961, pp. 256-257). No obstante, se desconoce si, como en el caso de Trujillo, se incluyó un cuestionario sobre datos demográficos y recursos naturales (Macera, 1997, p. 22). Posiblemente no fue así porque, en cierta manera, no era indispensable. Esta tarea ya se había realizado parcialmente por los oficiales burócratas en la década anterior por medio de los «estados de los partidos», en cumplimiento de la Instrucción para los subdelegados (arts. 7, 23-24, 26). Por ejemplo, en 1786, el subdelegado Manuel de Fonnegra presentó al intendente Mata Linares un cuadro con alto grado de descripción del partido de Tinta. ${ }^{11}$ En los mismos años de su visita pastoral, se continuaba con la preparación de estos reportes por funcionarios civiles, como la «Descripción de la provincia de Abancay» elaborado por Espinavete López, contador de las cajas reales de Huamanga, y publicado en 1795 en el Mercurio Peruano (Espinavete, 1795, pp. 112-164).

Las visitas pastorales de don Bartolomé María, según los primeros resultados de mi investigación, se centraron con mayor atención en temas pastorales, cofradías y prácticas sacramentales. ${ }^{12}$ En la celebración de los sacramentos debía palparse el cumplimiento de los lineamientos eclesiásticos y realistas. En cuanto a lo primero, la alta dignidad mandó que a pesar de que un difunto fuese declarado pobre de solemnidad, se debía celebrar la misa de cuerpo presente y no solamente vigilia cantada. La razón de este pedido, que contravenía el arancel, era para «estar más conforme a la mente del Señor Benedicto XIV y la piedad cristiana que debe sobresalir en los Párrocos» (Zegarra Moretti, 2015, p. 426). Como se conoce, el

11 AGI, Cuzco, 35, Estado del partido de Tinta.

12 Un acercamiento a la inspección realizada a la doctrina de Ayaviri (partido de Lampa, actual provincia de Melgar, en Puno), en Zegarra Moretti (2011a, pp. 94-95, 2012a, pp. 106, 136, 263). 
concepto de piedad cristiana y prácticas piadosas adquirieron una nueva dimensión en esta época para la expresión del cristianismo. A la par de ello, en estos ritos sociales y religiosos se debía seguir las normativas reales. En virtud de lo anterior y en ocasión de la realización de los bautizos de españoles, el mitrado decretó que en la partida se debía incluir los nombres y apellidos de los abuelos paternos y maternos en caso estuvieran vivos «por estar así dispuesto por reales nuevas pragmáticas» (Zegarra Moretti, 2012b, p. 301). Bajo el nombre de «pragmáticas» se conocen las regulaciones que normaron diferentes aspectos de la sociedad virreinal, siendo la dirigida a los matrimonios (1776) la de mayor repercusión de la etapa carolina. Revisando las actas de las visitas pastorales, inscritas en los libros parroquiales, es como podemos conocer el acatamiento y aplicación —al menos en términos formales - de las políticas realistas de los Borbones por los propios jefes episcopales.

Una evidencia adicional, que permite argumentar el apoyo del obispo cusqueño a los planes ilustrados, se da en ocasión del pedido de circulación de una publicación con contenido destinado al incentivo de la agricultura. La cabeza eclesiástica de Cusco respondió favorablemente, en junio de 1805, a la orden de Carlos IV del 2 de octubre de 1804 para adquirir ejemplares del Diccionario Universal de Agricultura, editado por el abad francés Jean-Baptiste François Rozier (1734-1793). ${ }^{13}$ La versión oficial argumentaba que este material permitiría la difusión de, en palabras de Bartolomé María, «los conocimientos más útiles de la Agricultura y Artes». El clero, al ser el operario de los planes de la Corona, estaba destinado a recibir la

13 Este pedido real hacía eco de otros del 22 de octubre de 1801 y del 3 de noviembre de 1802. En el primer caso se trató, según la documentación arribada a la diócesis de Santa Fe, del ofrecimiento del Seminario de Agricultura y Artes, publicación madrileña iniciada en 1797. A la sede colombiana también arribó la cédula comentada del 2 de octubre de 1804 que promulgaba la distribución de la obra de Rozier entre el clero para expandir «las luces que contiene entre sus feligreses» (Ots, 1958, pp. 288-289). 
obra señalada y aplicar su contenido. Así intentó disuadir el mitrado cusqueño a su clerecía: «asegurándoles que las utilidades que se esperaban venida la obra, cederían en felicidad de sus feligreses, y aun de ellos propios». En su mirada, ambos grupos encontrarían beneficio en el plan del rey. ${ }^{14}$

Manifestó el mitrado, posiblemente recordando sus visitas a la diócesis, que en varias regiones de su jurisdicción se padecía gravemente de «la falta de conocimientos, de reglas, y de industria». Por una parte, «la gente aplicada» se encontraba «reducida, a los cortos conocimientos que les surtía el ejercicio y la experiencia del trabajo, sin poder amejorar [sic] su suerte». Por otra, la falta del saber moderno mantenía «al resto en una vida ociosa», la cual «cada día crecía en vicios perjudiciales á la pureza de costumbres, y á la Religión en que vivimos». ${ }^{15} \mathrm{Al}$ detallar las gestiones y acciones realizadas para financiar la adquisición de «cuarenta o cincuenta ejemplares», concluyó: «Todo esto acreditará, el interés, empeño, y rendida obediencia con que lleno mi Ministerio, executo sin pérdida de tiempo las Ordenes de S.M». ${ }^{16}$ Esfuerzos de Las Heras para mostrarse como un servidor obediente.

Paralelo a las declaraciones y acciones reglamentarias emprendidas por el obispo Bartolomé María, otra forma de acercarnos a su postura es por medio de su biblioteca particular. De ella se dispone de dos descripciones en años claves. La primera es un inventario y tasación a cargo del doctor Juan Munive y Mozo, elaborado en Cusco en marzo de 1791, es decir, tras pocos meses de su asiento obispal (De la Puente Candamo, 1955) y la segunda fue realizada en

14 AGI, Lima, 769, Obispo Bartolomé sobre Diccionario de Agricultura del abate Rozier. La misma respuesta fue expresada por el obispo de Trujillo, José Carrión y Marfil, en julio de 1805 (AGI-Lima-769-Pedido de obispo de Trujillo), de quien, tras la llegada de San Martín en 1820, se confirmó su postura realista (Vargas Ugarte, 1962, pp. 142-145).

15 AGI, Lima, 769, Pedido del obispo de Cusco Las Heras, f. 1v.

16 AGI, Lima, 769, Pedido del obispo de Cusco Las Heras, f. 2v. 
1816, durante su gobierno arzobispal, en ocasión de la donación a favor del Seminario Santo Toribio, en Lima (Benito, 2018). La primera incluye setenta y cinco títulos y la segunda, según mi contabilidad, medio millar exactamente. Cabe hacer la mención de que, en el lapso de un cuarto de siglo y de estar a cargo de dos de las diócesis de mayor riqueza en Sudamérica, Las Heras multiplicó su colección privada por, al menos, siete veces. Vale realizar un comentario adicional de la cesión libresca ocurrida en la capital. Por tratarse de una transferencia en pleno gobierno episcopal y por el número redondeado de quinientos, invita a pensar que no abarcó la totalidad, sino una selección. Los límites del conjunto son desconocidos. A pesar de ello, las dos relaciones muestran un acercamiento representativo de las temáticas recopiladas por su propietario.

Al desconocerse la fecha exacta de adquisición de este material, he decidido realizar un análisis tomando en consideración ambas listas (1791 y 1816), puesto que permiten vincular los títulos con los intereses que veremos en los siguientes apartados. La reforma de los estudios y la moralidad del clero están presentes. En ese sentido, pueden encontrarse las constituciones que regían las universidades de Salamanca - que sirvió de modelo para muchas americanas-y las de Lima (Benito, 2018, p. 87), además de la obra de Francisco González, impresa en 1777, que lleva por título Instrucción para seminarios conciliares y eclesiásticos: obra útil para todo eclesiástico [...], y toda clase de personas que quieran hacer exercicios espirituales, y progresos en la virtud (Benito, 2018, p. 91). Se trata de un texto educativo dirigido a los obispos y conformado por un conjunto de ejercicios espirituales (diez «pláticas» y nueve «conferencias») y una relación de autores (entre ellos, Kempis) para formar a ministros que puedan «dar estos exercicios espirituales a Ordenados, Curas, Seglares, y Religiosas, y también para destinarlos a Misiones» (González, 1777, p. 271). La reforma de la disciplina del clero, mayúscula preocupación de la época, se esperaba conseguir por medio de estas técnicas. 
A pesar de lo anterior, considero que la distinción más representativa de la colección de Las Heras es el material sobre el derecho canónico. ${ }^{17}$ En ese sentido, abundan referencias en torno a la vertiente indiana y la enseñanza universitaria de este saber. Merece ser subrayada la presencia de legislación canónica producida en América por medio de concilios - los mexicanos en edición del arzobispo de México, Francisco de Lorenzana- ${ }^{18}$ y sinodales — los de Chile- (Benito, 2018, pp. 92, 97). Este material es central en la formación del derecho canónico indiano, al otorgar al corpus universal las peculiaridades de la vida americana (Salinas, 2000, pp. 228-229). De la colección de don Bartolomé María merece convocar a los siguientes personajes: Azpilcueta, Barbosa, Frasso, Lanceloto, Murillo, Reiffenstuel y Villarroel (Benito, 2018, pp. 83-84, 90, 92, 94, 96, 99). Todos ellos respetados canonistas (Salinas, 2000, pp. 217, 222; Terráneo, 2017) y cuyas obras — sobre todo de Pedro Murillo con Curso del derecho canónico y Anacleto Reiffenstuel con Cuestiones sobre el derecho canónico - eran las utilizadas para la enseñanza del derecho canónico en América (Salinas, 2000, p. 222; Terráneo, 2017, p. 140).

El citado repertorio de egregios jurisconsultos tenía sintonía con las enseñanzas del principal seminario del virreinato. No obstante, el claro interés de don Bartolomé María en temas canónicos —que incluyen temas álgidos como el regalismo- no nació en la silla arzobispal. Su inclinación hacia el derecho canónico tuvo un capítulo cusqueño en donde incentivó su estudio y aplicación. El siguiente apartado se dedica a la valiosa huella dejada por el obispo andaluz en lo que respecta a la difusión de la ciencia jurídica en nuevos espacios y al perfil profesional del clero diocesano.

17 Este mismo rasgo ha sido resaltado para bibliotecas pertenecientes a otros obispos americanos de la segunda mitad del siglo dieciochesco. Para el caso de Antonio Bergosa y Jordán (obispo de Oaxaca) y de Manuel Ignacio González del Campollo (obispo de Puebla) (Gómez y Coudart, 2002, pp. 311-312).

18 Sobre la labor editorial de Lorenzana, véase Vizuete Mendoza (2014). 


\section{El FRENTE LETRADO}

De la poca conocida labor de Bartolomé María al frente de la diócesis cusqueña quisiera profundar en un aspecto: la educación jurídica a nivel universitario. En ese sentido, el obispo inauguró una nueva etapa en la historia de la universidad San Antonio Abad al fundar formalmente, mantener y controlar las cátedras de derecho civil y canónico. En efecto, una de las primeras acciones que se realizó en el centro antoniano fue el nombramiento de catedráticos en los dos derechos.

El 22 de octubre de 1791, el obispo Bartolomé convocó al concurso para ocupar la primera cátedra de derecho civil, dotada con salario de 200 pesos anuales (Valcárcel, 1953, pp. 168-169; Villanueva Urteaga, 1963, p. 20). ${ }^{19}$ Respondieron a la oposición tres candidatos: el abogado Dr. Rudecindo Tomás de Vera, el abogado Dr. Miguel de Vargas y el bachiller Agustín Ampuero y Zegarra, este último «teólogo pasante del mismo Seminario [San Antonio Abad] y practicante de leyes» en la audiencia cusqueña (Valcárcel, 1953, p. 169). Tras ser evaluados en asuntos de Instituciones de Justiniano, el rector, José Pérez y Armendáriz, justificó su preferencia sobre el primer postulante «por su suficiencia, antigüedad, y arreglada conducta con que se ha granjeado la mejor reputación en esta Ciudad». Agregó otro motivo sustancial: «como también porque en todo este tiempo ha enseñado y promovido los Estudios del Derecho en este Colegio asistiendo y presidiendo las funciones, sin más objeto que el de mirar por el lustre y adelantamiento de nuestro Seminario» (Valcárcel, 1953, pp. 171-172). Sin mayor contradicción, el mitrado invistió al letrado Rudecindo Tomás de Vera, «colegial que fue de dicha Casa», en el cargo de primer catedrático de prima de leyes con fecha del 12 de abril de 1792 (Valcárcel, 1953, p. 173).

19 En los mismos años, concretamente en 1793, se realizó la fundación de cátedras de derecho civil y canónico en la Universidad de Córdoba (Yanzi, 2002, p. 1863). 
Respecto a la cátedra de cánones se abrió a concurso en octubre de 1793. Los opositores admitidos fueron solamente dos: el Dr. Toribio de Hermosa, catedrático de nona de Teología y bachiller en ambos derechos, y el Dr. Hermenegildo de la Vega, catedrático de filosofía e, igualmente, bachiller in utroque iure. Ambos fueron evaluados en las Decretales de Gregorio IX, siendo elegido el segundo como catedrático titular de la plaza y confirmado por el obispo en mayo de 1794 (Valcárcel, 1953, pp. 174-182).

Claros indicios me llevan a considerar que las previas designaciones suponen solamente la formalización de los estudios de leyes en San Antonio. Estos se venían realizando sin contar con la institucionalización de las cátedras ni la autorización respectiva. Lo anterior se basa en la ya mencionada justificación de la elección de don Rudecindo Tomás de Vera por parte del rector, quien subrayó que «en todo este tiempo ha enseñado y promovido los Estudios del Derecho en este Colegio» (Valcárcel, 1953, pp. 171-172). La instrucción en Derecho sin cátedra era una práctica que también se puede intuir en otros seminarios vecinos (Salinas, 2000, pp. 218-219). Un argumento de mayor contundencia es la propia queja de la Audiencia de Cusco manifestada en sus primeros años de funcionamiento a fines del siglo XVIII. En un informe al Consejo de Indias la judicatura indicó que la universidad cusqueña venía confiriendo grados «en Leyes, Cánones y Medicina» sin tener la respectiva facultad para ello. ${ }^{20}$ Desconocemos desde cuándo se realizó esta práctica, pero la formalización llegará, como se ha anotado antes, a partir de octubre de 1791. Este aserto es valioso en cuanto documenta la instrucción jurídica en San Antonio, aunque sea en una aparente ilegalidad, en fechas anteriores a lo que se postula en la historiografía (Villanueva Urteaga, 1963, pp. 20-21).

Además de la formalización, Las Heras controló el ejercicio de los catedráticos de leyes, apostando por un sistema público de

20 AGI, Lima, 602, Razón del estado de la Universidad San Antonio Abad. 
nombramientos que mantenga y promueva la competencia intelectual entre los candidatos. En ese sentido, se mostró en contra de los nombramientos de «catedráticos futuros». En efecto, al momento de la elección de Rudecindo Tomás de Vera, se nombró, asimismo, al abogado Miguel Vargas como catedrático «en ausencia o enfermedad» del titular, así como futurario cuando el titular «se promoviese á algún empleo incompatible, ó vaque esta de cualquier modo» (Valcárcel, 1953, p. 172). Lo mismo sucedió para la cátedra de Prima de Cánones, donde Hermenegildo de la Vega tenía como suplente y sucesor a Toribio de Hermosa, quien la asumiría «si quisiese sin nueva oposición» (Valcárcel, 1953, pp. 179-180). Para el obispo, la figura de catedrático futurario — mas no de suplente- formaba parte de procedimientos «irritantes que deben revocarse» y que no coinciden con «la practica universal de las universidades». Por tales razones, no hesitó en dejar sin validez los nombramientos realizados (Valcárcel, 1953, p. 180). La postura de Las Heras, expresada en mayo de 1794, estaba respaldada en la inesperada buena acogida que habían tenido los estudios de leyes desde su institucionalización. ${ }^{21}$

El obispo reconoció que la principal razón que llevó, escasos años atrás, a aceptar el nombramiento anticipado del catedrático sucesor fue que, en ese momento, encontró en Cusco una «falta de sugetos Juristas que pudiesen contraherse a su desempeño». Preocupado por no poder disponer de maestros tomó tal decisión: «por lo cual recelosos de que en lo sucesivo se experimentase igual escases, y que no hubiese quien se dedicase á servirla, nos pareció conveniente admitir por entonces la propuesta de la enunciada fu-

21 Es posible que el obispo haya tenido en mente los proyectos reformistas que se aplicaron en las universidades españolas durante la regencia de Carlos III. Si bien no he encontrado referencia a catedráticos futurarios, sí existió en la época la figura de suplente (Álvarez de Morales, 1979, p. 95). No obstante, las motivaciones carolinas se dirigían a dar prioridad «al mayor mérito y aptitud» al momento de otorgar cátedras (Álvarez de Morales, 1979, p. 96). 
tura», confesó. Pero en opinión del mitrado esta situación había rápidamente cambiado. Satisfecho afirmó: «han cesado en el día con su establecimiento [de la cátedra de derecho civil] las causas que nos impelieron á ello». Entre 1792 y 1794 se había registrado, siguiendo al prelado, una copiosa cantidad de alumnos «que ocurren á la Catedra de Leyes, y se han aplicado á su estudio, de los que algunos han consumado su curso, y se hallan en estado de enseñar la facultad», por lo que «no puede continuar el nombramiento de Catedrático futuro» (Valcárcel, 1953, p. 181).

No era únicamente por disponer de un espectro mayor de candidatos al momento de designar al docente titular, sino se trataba sobre todo de calidad. La exigencia académica del mitrado se deja apreciar cuando se opuso al puesto de catedrático futuro porque eso produciría una desmotivación y aletargamiento intelectual de los potenciales instructores. De este modo, al ya estar la cátedra asignada por dos vidas generaría que en los posibles interesados escasease «el estímulo de optarlas, y consiguientemente dexaria de exitarse en los ánimos [...] aquel noble impulso que los empeña en su Carrera á la mayor aplicación y adelantamiento» (Valcárcel, 1953, p. 181).

Otro cambio impuesto por Las Heras en cuanto a la elección de catedráticos fue que anuló un requisito que había estado presente en las convocatorias anteriores. A partir de ese momento, ya no sería condición para la postulación que el candidato haya sido colegial o, por un mínimo de tres años, docente en San Antonio. La intención de ello era que, en la visión del prelado, «estas Cátedras [de derecho] deben ser publicadas» y que «generalmente sean admitidos qualesquiera sugetos», primando que «sean decentes»y «su habilidad, graduación, y méritos que hayan contraido en cualquier forma» (Valcárcel, 1953, p. 181). ${ }^{22}$

22 En este apartado, el obispo se alineaba a las reformas carolinas. En una carta orden de 1768, las autoridades españolas establecieron que, en palabras de Ál- 
Como se deja ver de las referencias anteriores, los planes del obispo en la profesionalización del clero en materias jurídicas cosecharon rápidamente frutos. Uno de ellos fue José Manuel Campana, cura de Acha Hanansaya y graduado en enero de 1802 de San Antonio. Concluida la etapa formativa, solicitó a la judicatura cusqueña, en diciembre de 1802, «resivirse á Practica de Abogado en los Estrados de esta Real Audiencia», lo cual fue aceptado por las respectivas autoridades bajo una desalentadora condición. Se pedía al solicitante que su etapa de practicante no interfiera con sus labores pastorales, por lo que buscase para las prácticas un «estudio de Abogado de estudio conocido que huviere en dicho su curato». ${ }^{23}$ Tal requisito puede ser leído más bien como un mal intencionado impedimento, ya que los despachos de letrados se concentraban en su mayoría en el casco urbano. No he podido seguir la carrera legal de Campana, aunque sí la eclesiástica, llegando a ser cura propio de Orurillo (partido de Lampa) entre 1805 y 1814 (Zegarra Moretti, 2011b, p. 156).

Por lo anterior, es correcto afirmar que el obispo cusqueño había puesto en la formación universitaria en materias jurisprudenciales un interés superlativo. Estableció las dos cátedras que constituían los pilares de la formación jurídica de ese tiempo, las dotó de salario y se preocupó por que sean motivo de mejoramiento intelectual. Ahora toca ocuparnos de una inevitable cuestión: ¿cuál era el interés del prelado en el Derecho? Para ello se dispone de la propia explicación del responsable. En primer lugar, Las Heras consideraba que entre el clero cusqueño existía «muy escaso [...] número de Eclesiásticos que poseen el conocimiento de las Ciencias sólidas de Leyes, y Sagrados Cánones». La sólida preparación de su clerecía («cuyo estudio, e instrucción es indispensablemente necesa-

varez de Morales, «la oposición debía estar abierta a los graduados de las demás Universidades del Reino» (Álvarez de Morales, 1979, p. 99).

23 Archivo Regional de Cusco [ARC], Real Audiencia [RA], Leg. 162, Exp. 46. 
rio», llegó a afirmar) era vista como una ayuda vital «en mucha parte del Gobierno de nuestro Ministerio Pastoral» (Valcárcel, 1953, pp. 168-169). Así lo manifestó en 1792, y lo reiteró con total claridad dos años después: el clero estaba llamado a ayudar al prelado «en el grave peso de nuestro ministerio pastoral» (Valcárcel, 1953, p. 180). Para remediar esa sequía profesional una solución fue la reforma educativa en el seminario universitario antoniano, pero era una medida frágil.

La Audiencia de Cusco, instalada en 1787, no miraba con buenos ojos los cambios que se producían en los claustros de San Antonio, un espacio donde el obispo Las Heras venía implementado serias reformas, y cuyos muros se resistían al punzante influjo del vicepatronazgo que ostentaba el tribunal superior. Esto llevó a que la judicatura cusqueña se inmiscuya, por lo que privó a las autoridades antonianas, en octubre de 1798, «la facultad de conferir grados en Leyes, Cánones y Medicina a toda clase de personas, permitiéndolo solo en Teología y Filosofía» (Villanueva Urteaga, 1963, p. 22). La dignidad episcopal no dejó de reaccionar y elevó, en noviembre de 1799, un reclamo al rey español. Tuvo éxito, ya que desde España, en enero de 1802, se decidió que el claustro siga otorgando grados en derecho (Villanueva Urteaga, 1963, p. 22). Se desconoce la fecha de recepción de la reapertura del proyecto, pero coincide con la fecha del título del cura Campana, ya aludido, el cual, posiblemente, debió esperar la resolución de la tensa coyuntura entre las dos cabezas cusqueñas. $^{24}$

Por las dificultades que le ponía la audiencia, el mitrado debió ser consciente que la implementación de un entorno letrado no podía depender únicamente de San Antonio. Era necesario idear otras estrategias en paralelo para cumplir su objetivo. En ese sentido, la

24 Tensiones entre autoridades eclesiásticas y funcionarios de audiencias por el control sobre la educación universitaria sucedieron, en años contemporáneos, en el Nuevo Reino de Granada (Uribe, 1996). 
profesionalización de agentes que intervenían en el desarrollo de procesos judiciales y asuntos extrajudiciales, así como la consagración clerical de letrados clave fueron vías usadas por el obispo.

En virtud de lo anterior, Las Heras aseguró que titulados en leyes intervengan en la administración de justicia. El ya mencionado Rudecindo Tomás de Vera, primer catedrático de Prima de Derecho civil, se convirtió en el notario mayor de la curia eclesiástica. La evidencia más antigua que he podido hallar de su ejercicio escribanil data de octubre de $1790,{ }^{25}$ el mismo año de llegada del obispo andaluz a tierras cusqueñas. Un rasgo adicional por subrayar de la vinculación de Rudecindo Tomás de Vera a los planes del prelado es que no era típico que un letrado posea y conduzca una escribanía. La tendencia dominante en el perfil de propietarios de notarías era de sujetos con experiencia práctica y cotidiana del andamiaje del derecho, y no letrados titulados. ${ }^{26}$ De la misma manera, en la administración de la justicia eclesiástica el puesto de promotor fiscal tenía un significativo rol. En el tiempo de nuestro obispo tenemos referencias de al menos tres propietarios: Lic. Agustín José de Sánchez en 1793 (Unanue, 1793, p. 234), Dr. Domingo Bustos entre 1794 y 1796 (Unanue, 1794, p. 192; 1796, p. 215) y Dr. Matías Isunza en 1797 (Unanue, 1797, p. 196). En el estado actual de mis investigaciones, puedo indicar que entre ellos se entremezclaban tres rasgos: cura, ${ }^{27}$ abogado y docente en San Antonio. ${ }^{28}$

25 ARC, RA, Leg. 5, Exp. 11.

26 Sobre los escribanos cusqueños, véase Burns (2011). En la normativa canónica americana - por ejemplo, en las Sinodales de Caracas - no se especificó el rasgo letrado para los notarios de las audiencias episcopales (Sinodales de Caracas, 1986, pp. 158-162).

27 Sobre letrados en las filas clericales, véase, para el caso de Nueva Granada, la breve alusión en Uribe (1995, p. 530).

28 Bustos fue abogado (ARC, RA, Leg. 164, Exp. 8), cura de Santa Ana entre 1796 y 1797 (Archivo Arzobispal de Cusco [AAC], LP, Santa Ana, Bautizos, 17861797; Unanue, 1797, p. 197); a su vez, en los primeros años de 1792, el Dr. Bustos fue preceptor de latinidad en San Antonio y obtuvo en octubre de 1792, por 
Otra interesante estrategia que implementó Las Heras para incorporar a su séquito a personajes letrados fue la ordenación sacerdotal. El ejemplo más elocuente fue Juan Munive y Mozo, quien obtuvo las órdenes sagradas luego de recibirse de abogado y desarrollar una rampante carrera en Cusco. En ese sentido, Munive y Mozo fue asesor del ayuntamiento de Cusco en 1784, ${ }^{29}$ adquirió, asimismo, experiencia en la docencia siendo, en 1788, examinador de materias de Instituciones Romanas y Castellanas en el colegio real San Bernardo. ${ }^{30}$ Por último, instituida la audiencia cusqueña, ocupó los cargos de asesor fiscal y protector partidario entre 1789 y $1790 .{ }^{31}$ Este año parece ser la última vinculación entre Munive y Mozo y las instituciones civiles. A inicios de la década de 1790 — que coincide con la llegada del obispo Las Heras - la curia convenció al letrado para continuar entre sus filas su desempeño profesional. En agosto de 1792 lo encontramos ya con el poderoso título de provisor y vicario general del obispado. ${ }^{32}$ Sabemos que fue sacerdote porque en 1795 era el cura propio de Cupi ${ }^{33}$ y de San Jerónimo, a partir de 1797 (Unanue, 1797, p. 197) y por casi dos décadas (Ruiz, 1817, p. 10). ${ }^{34}$

medio de concurso, la cátedra de filosofía (Valcárcel, 1953, p. 174). Por su parte, Isunza fue sacerdote, abogado (ARC, Cab., Leg. 50, Exp. 1183, ff. 33v, 34v), y cura rector de la parroquia de San Sebastián (ARC, RA, Leg. 118, Exp. 6, F. 2v). Fue notario mayor antes de la llegada de Las Heras. Al igual que para el caso de los notarios eclesiásticos, no se especificó en las normativas de la época el rasgo letrado para el oficio de promotor fiscal, aunque sí la necesidad de su condición eclesiástica (Sinodales de Caracas, 1986, pp. 153-158). Del licenciado Sánchez no he podido recabar aún datos adicionales.

ARC, Cabildo, Leg. 55, Cuad. 15, Exp. 1327.

30 ARC, RA, Leg. 4, Exp. 3, f. 2r.

31 ARC, Correg., Leg. 29, Cuad. 17.

32 AAC, Colonia, XLVI, 1, Exp. 11, f. 13v.

33 AGI, Cuzco, 24, Marcos Tapia.

34 La estrecha vinculación entre el obispo y el cura letrado - el mismo que, recordemos, realizó el inventario y tasación de sus libros - se confirma por una declaración del fiscal único de la audiencia local, Antonio Suárez, al mencionar 
Por diferentes vías, el obispo de Cusco, Bartolomé María de las Heras, se preocupó por formar un clero letrado. Ellos estaban llamados explícitamente a servir de apoyo a su pastor. ¿Para qué los utilizó?, ¿qué tenía exactamente en mente cuando consideró que el clero instruido en leyes debía aliviar «el grave peso de nuestro ministerio pastoral» (Valcárcel, 1953, p. 180)? Entre los diferentes fines que ello pudo significar, uno me parece claro: intentar proteger los privilegios de la Iglesia americana, que el regalismo ibérico venía devorando imparablemente.

\section{La Real cédula de 1784 en Cusco}

De la batería de reformas borbónicas que afectaron a la administración económica y judicial de las diócesis americanas se encuentra la real cédula promulgada el 27 de abril de 1784. Dicha disposición legal, cuyo impacto en el virreinato peruano ha sido poco advertido, afectaba a un grupo específico de testamentarias, que el fuero eclesiástico controlaba y de las que se beneficiaba económicamente..$^{35}$ En efecto, establecía que las causas sobre las testamentarias de eclesiásticos y aquellas en las que los bienes eran dejados a obras pías ya no continúen siendo vistas por el juzgado episcopal, sino en exclusividad por el civil. «Para que en los reinos de Indias no se permita a los tribunales eclesiásticos el conocimiento sobre validación o nulidad de testamentos,

que formaban una alianza en contra de la autoridad civil (AGI, Estado, 75, N. 24, f. 19v).

35 De la cédula real de 1784 se conoce un artículo (Sánchez Bella, 1986) que se ocupa de mostrar las entretelas de la promulgación del decreto mencionado, destacando las discusiones previas entre virreyes americanos, el Consejo de Indias y el monarca español. Es mencionada por Levaggi (1992, p. 84) como antecedente de la cédula del 22 de marzo de 1789 sobre la jurisdicción real de capellanías y obras pías, y precedente de la del 20 de noviembre de 1801. 
inventarios, depósitos o secuestro de bienes, aunque los testadores o herederos sean eclesiásticos u obras pías», decretaba el supremo documento. $^{36}$

Como se puede advertir en la cita, la ordenanza se dirigía explícitamente a los obispados ultramarinos, y ponía la mira sobre las causas testamentarias, que incluían varios actores, procesos y circunstancias. De esta forma, se quitaba una potestad que gozaba la Iglesia católica ubicada en los territorios americanos. Sin embargo, no era el primer intento ni el último de la Corona en luchar por obtener esta exclusividad, gracias a la cual le permitía tener acceso a un copioso fondo económico debido a la sacralización de la sociedad y la preocupación del destino del alma tras la muerte. ${ }^{37} \mathrm{El}$ enfrentamiento entre el poder regio y el eclesiástico en esta materia típica del fuero mixto enfrentaba dispositivos legales (dígase las leyes reunidas en las recopilaciones de Castilla y de Indias, o las Sinodales de Caracas de 1687) ${ }^{38}$ y argumentos canónicos, los cuales en algunos casos llegaron a ser contradictorios y enmarañados. En ese contexto, la cédula real de 1784, como pondera Farriss (1995, pp. 146-153), representa una verdadera y clara imposición por parte del gobierno español a favor del fuero civil.

36 La reproducción íntegra de esta cédula se encuentra en el anexo de este artículo. Esta decisión responde a la poca accesibilidad de su contenido en la producción reciente y no haber sido reproducida en su totalidad por Matraya y Ricci (1978, p. 382) ni Sánchez Bella (1986, pp. 252-253).

37 Fisher (2000, p. 87) puntualiza que la junta superior de consolidación acopió, hasta 1808, un aproximado de millón y medio de pesos de fuentes procedentes de capellanías y obras pías.

38 De las Sinodales de Caracas se dispone tres ediciones: la primera de 1698, la reimpresión de 1761 en tiempos de Carlos III y la más reciente de 1986 (SantiagoOtero, García y García y Soto, 1986, p. LXII*). 


\section{LA DEFENSIVA DEL CLERO CUSQUEÑo}

Será a raíz de la aplicación de la real cédula de 1784 en Cusco, cuando el obispo Bartolomé María reunirá su frente letrado para establecer una defensa de los derechos de las Iglesias americanas. Se produjo en 1796, después de doce años de la promulgación del decreto supremo y luego de seis años de presencia del mitrado andaluz en la silla cusqueña. La ocasión fue la testamentaria del párroco urbano, Marcos Tapia, estrechamente vinculado con el cabildo catedralicio. En su última voluntad, registrada el 19 de junio de 1790, declaró a su alma por heredera universal. ${ }^{39}$ Asimismo, instituyó como albacea principal a Francisco Aldazábal, canónigo magistral de la iglesia de Cusco, a quien nombró además tenedor de bienes. Los segundo y tercer albaceas fueron, igualmente, eclesiásticos: Fr. Pedro de la Sota, de la Redención de Cautivos, y Fernando Trelles. Es decir, el caso reunía todas las condiciones en los que debía aplicarse la cédula de 1784 y ser tratado en el fuero civil.

Tras la muerte de Tapia, fue en el cabildo civil de Cusco donde se procedió con las gestiones testamentarias, habiéndose realizado la apertura, el inventario de bienes y las diligencias de acreedores. En ese momento es cuando intervino el canónigo Aldazábal y principal albacea, quien requirió al obispado reclame que la causa sea atendida bajo la jurisdicción eclesiástica. En ese sentido, consideró al ayuntamiento secular un «juzgado incompetente para el conocimiento de las mencionadas demandas». Por este motivo,

39 En los últimos años de vida, en 1793, Tapia había sido designado albacea de Bernardo Jayo, cura de Orurillo (partido de Lampa) y quien llegase a ser mayordomo del obispo Moscoso y Peralta, reflejando su «buena cercanía» con la mitra cusqueña (AGN, AE, Leg. 95, Exp. 105). El presbítero Tapia pasó sus últimos años en la capital cusqueña, lugar de mayor influencia legal que las periferias. Bajo su cuidado estuvieron las parroquias de Belén y Santiago desde, al menos, 1785 hasta su muerte (ARC, Not., Arias de Lira, Prot. 44 [antes Prot. 41], f. 614v). Poco más es lo que conocemos de la vida de don Marcos, salvo el nombre de sus progenitores: don Josef de Tapia y doña Juana Maranbio (AGI, Cuzco, 24, N. 6). 
demandó al obispo que presente un exhorto dirigido al alcalde «para que absteniéndose, e inhibiéndose del referido conocimiento, remita los Autos que hubiese obrado». Uno de los argumentos centrales que planteó fue el contenido del acuerdo del Consejo de Indias insertado en las Constituciones Sinodales de Caracas de las últimas décadas del siglo XVII (147, título 13, libro 4). Como él mismo indicó, en la reunión celebrada en 1687, se estableció «que cuando el clérigo deja su ánima por heredera, el conocimiento de todas las causas y pleitos que se pusieren contra los bienes de la herencia, a pedimento de los legatarios o acreedores, toca a la Justicia Eclesiástica». ${ }^{40}$

Estas potestades eclesiásticas fueron rigurosamente limitadas por la cédula de 1784, que, para entonces, ya era ampliamente conocida. Recordemos que ella no autorizaba a los tribunales eclesiásticos conocer acerca de validación, nulidad de testamentos, inventarios, secuestros ni depósito de bienes si son testadores o herederos clérigos o dejan a sus almas por herederas. Empero, para Aldazábal, esta normativa no era del todo precisa en esta materia, ya que de manera enfática no suprimía el auto anterior donde se da potestad privativa al tribunal eclesiástico en los casos en que el clérigo dejaba a su ánima por heredera para el conocimiento de las causas de testamentaria de herencia recaída en legatarios o acreedores. Consideró sobre la cédula de 1784, que únicamente «prohíbe que los Tribunales Eclesiásticos conozcan de nulidad de testamentos, y que hagan inventarios, secuestros y depósitos de los bienes que dejasen los Testadores, sin embargo del dicho auto». Agregó que «es evidente que no está corregido más que en cuanto a la facción de inventario, y que así debe subsistir en cuanto al conocimiento de las causas». Es decir, a pesar de las puntuales diligencias a cargo del tribunal secular, el conocimiento general y potestad sobre las causas seguían bajo jurisdicción eclesiástica, ya que la real cédula de 1784 no contradecía las potestades eclesiásticas de manera explícita.

40 AGI, Cuzco, 24, N. 6, F. 2r. Cf. Sinodales de Caracas [1848], pp. 307-308. 
Teniendo en cuenta esta consideración, desde el obispado se pasó vista al fiscal promotor de la diócesis, el ya mentado cura abogado Bustos. Él secundó el planteamiento de Aldazábal. Con estos razonamientos, Munive y Mozo, en calidad de provisor y vicario general del obispado, exigió al cabildo, a cargo del alcalde de segundo voto, Marcos Fortón, que detenga las diligencias, ya que competían privativamente al fuero eclesiástico. Esto derivó en un escrito del abogado y de uno de los acreedores, defendiendo la jurisdicción real. Tras esta réplica, desde el obispado se pidió al promotor la elaboración de una réplica. El asunto podía seguir así, sin encontrar fin.

Ambas partes coincidieron en que no había acuerdo. Desde la curia se evitó que el asunto erosione y llegue a un fuerte escándalo público, por lo que se debía proceder con tacto. Por tal motivo, el obispo Las Heras, argumentando imprecisión en la cédula real de 1784, consideró pertinente hacer la consulta directamente al Consejo de Indias, utilizando una vez más su red de contactos. En el expediente preparado para tal fin se resaltó que la nueva normativa no dejaba en claro «a qué Jurisdicción corresponde el conocimiento de las Causas suscitadas contra la testamentaria en que es heredera el Alma, o nombrado Clérigo por heredero». La propia dignidad episcopal detalló, el 10 de septiembre de 1795, que:

[...] antes bien, conforme al Espíritu de esta Real Disposición, parece, que no dirigiéndose las citadas causas contra un todo indefinido, cual es el que se compone de los Bienes hereditarios, cuando se trata de la apertura de testamento, inventarios, tasación, y secuestro de bienes, o sobre la nulidad del mismo Testamento, sino contra interesados ciertos y determinados, como son el Alma, o Clérigo herederos; debe conocer de dichas causas la Jurisdicción Eclesiástica por el privilegio y fuero de los Demandados. ${ }^{41}$

41 AGI, Cuzco, 24, N. 6, ff. 2r-2v. 
En otras palabras, en la interpretación jurídica que encabezó el prelado cusqueño, la cédula de 1784 no es causa de privación de jurisdicción al fuero eclesiástico en este tipo de asuntos. Al no precisar el punto sobre el alma o clérigos herederos, las causas testamentarias de este tipo debían, por tanto, seguir bajo la justicia eclesiástica.

Cuando recibió el pedido proveniente de Cusco, el Consejo de Indias sometió a consideración los puntos de ambas partes. Tras ello, emitió su contundente resolución el 28 de junio de 1796, exponiendo que no es admisible la duda expresada por el obispado. Asimismo, de manera rotunda expresó, en posible alusión al brocardo In claris not fit interpretatio, que el monarca español «declaró por regla general e invariable, que no recibiese interpretación en lo sucesivo». Es decir, como parte del cambio de la concepción del Derecho de la época, se imponía un mayor respeto a la ley escrita en desmedro de interpretaciones locales, tendencia que, sin embargo, no llegó a tener éxito en el espacio peruano (De la Puente Brunke, 2008, p. 52).

Seguidamente, expuso que por medio de reiteradas cédulas se enfatizó que los tribunales eclesiásticos indianos no tomen «conocimiento sobre validación o nulidad de testamentos, secuestro, o depósito de bienes, en que los testadores, y sus herederos fuesen clérigos, o aquellos dejasen por heredera su alma, u otras obras pías por corresponder todo a las justicias reales». Continuó expresando la jurisdicción real sobre la eclesiástica en temas testamentarios:

Que lo mismo se observase en los adhintestatos de Clérigos, y en los de Legos, cuyas herencias correspondiesen á Eclesiásticos, lo cual guardasen, y ejecutasen los Juzgados de Bienes de Difuntos, en los Casos, que tocasen a su conocimiento expresamente todas las órdenes, Cédulas, y cualquier costumbre, o práctica, que hubiese en contrario, y señaladamente el auto acordado inserto en el título 13 libro $4^{\circ}$. de las Sinodales del obispado de Caracas, mandando a los Fiscales, que con la mayor actividad defendiesen la Real Jurisdicción en este punto, y a los Virreyes, Audiencias, y demás Justicias de aquellos Reinos el puntual cumplimiento. 
En la cita anterior se patentiza la supremacía de la ley regia frente al derecho consuetudinario y, sobre todo, a la legislación canónica americana, representada en las Sinodales de Caracas, rasgos claves del derecho indiano provincial (Tau Anzoátegui, 2005, pp. 93-94). Dictaminó el Consejo de Indias, pues, que «lo actuado en el Juzgado Eclesiástico del Cuzco fue totalmente contrario a las leyes, y a dicha Real Cédula». Esta postura es repetida y respaldada por el monarca español el 21 de julio de 1796, quien consideró errónea la consideración del promotor fiscal de la diócesis de Cusco, «que las demandas promovidas contra la testamentaria de don Marcos de Tapia, de que pretendía conocer eran accesorias a la misma testamentaria» y «que siendo Juez privativo de esta el Alcalde ordinario lo había de ser de aquellas, así por los principios elementales del derecho, que previenen siga el Accesorio lo principal, como también por no dividir la continencia de la causa». Rogó y encargó el rey al obispo que estas autoridades «en lo sucesivo observen las Leyes y Reales disposiciones, y no opongan a su cumplimiento con pretexto de dudas imaginarias o afectadas, dándome aviso de haberlo practicado para su debida constancia». ${ }^{42}$ Así se zanjó el asunto con saldo negativo para la diócesis cusqueña.

Desde el Consejo de Indias no se limitó a dirigir la respuesta al obispo. Con el fin de asegurar el cumplimiento de una cédula real que buscaba otorgar más control al aparato real sobre las iglesias ultramarinas, el supremo organismo despachó un duplicado del asunto a la audiencia de Cusco el 20 de agosto de 1796. Al parecer, la consulta del obispado surperuano no fue la única recibida por el consejo español, ya que se aluden a cuestionamientos similares, como el del arzobispado de La Plata, con los mismos resultados. ${ }^{43}$

42 AGI, Cuzco, 24, N. 6, ff. 7r-7v.

43 AGI, Cuzco, 24, N. 6. 


\section{Conclusiones}

Con la respuesta del Consejo de Indias se hizo sentir la vigencia del regalismo en el palacio obispal cusqueño y entre sus pasillos transitó desilusionado el clero letrado que había armado la contraofensiva a la real cédula de 1784. A pesar de las duras palabras del rey español, la iniciativa tiene un significado que debe ser destacado. En primer lugar, nos permite discutir el rol de los mitrados en el siglo XVIII ante las reformas hacia la Iglesia.

Se ha manifestado que «la reforma eclesiástica tuvo el apoyo de obispos importantes que compartían las ideas principales de la ilustración católica y el regalismo» (Rosas Lauro, 2009, p. 148). En ese sentido, podemos incluir a Las Heras dentro del grupo de obispos inclinados a la Ilustración y que apoyaron los proyectos de la Corona española. Lo último quedó expresado claramente durante las visitas pastorales y el pedido de ejemplares del manual práctico de agricultura. No obstante, su gobierno episcopal en Cusco no fue únicamente la de un fiel servidor, sino sirve de invitación para volver a analizar el desempeño del episcopologio en la centuria dieciochesca.

Del significado, intenciones y estrategias de los mitrados contra las políticas borbónicas no se ha investigado suficientemente, interpretándose las rencillas únicamente en el plano de disputas personales y sin mirar por el posible cuestionamiento de los planes reales. La discusión en torno a la real cédula de 1784 nos permite mostrar que la categoría de «obispo ilustrado» como funcionario realista merece específicos matices y nos ha revelado la complejidad y agencia de estos relevantes sujetos.

He intentado demostrar que la real cédula de 1784 ofreció ocasión a Bartolomé María de las Heras y a su entorno para realizar un intento arriesgado de recuperación de las jurisdicciones que absorbía el regalismo. Fue posible gracias a dos motivos: el uso de la herramienta jurídica y el proceder diplomático. Si bien la mentada cédula cortaba a la diócesis la administración de ingentes fuentes 
económicas, el control de testamentarias vinculadas al clero y/o a la economía espiritual era una cuestión que conllevaba una fuerte fundamentación jurídica y complicada praxis. El clero letrado de don Bartolomé, en sintonía con su pastor, estaba listo para ponerse a prueba. ${ }^{44}$ La estrategia principal giró en torno al derecho canónico, que el obispo había fomentado en el plano educativo y práctico.

El desarrollo de las cátedras de leyes en San Antonio y la integración de letrados al círculo obispal permitió formalizar un frente de defensa legal. La ilustración católica se preocupaba por la formación del clero, pero no quedó únicamente en el plano espiritual. Aunque con obstáculos, la profesionalización llegó al plano académico por medio del derecho canónico (punto de interés en común en los tres obispos estudiados), el cual tenía, a su vez, una clara utilidad de defensa de las jurisdicciones codiciadas por los promotores del regalismo. Eso ofreció una herramienta de defensa entre los márgenes aceptables, pero no fue el único ingrediente para intentar frenar el regalismo.

Además del planteamiento teórico jurídico del accionar del obispado cusqueño, la maniobra de Las Heras incluyó un segundo aspecto clave: la gestión prudente de sus reclamos. Sin duda, el mitrado no fue el único que se mostró en contra de ciertas medidas regalistas, pero él acertó en la exteriorización de su desacuerdo sin ocasionar consecuencias desfavorables. Tenía claro que sus acciones no podían ofender a las autoridades de quienes, al final de cuentas, dependían las promociones eclesiásticas o, por el contrario, su destitución. ${ }^{45}$ No debemos olvidar que Las Heras fue ascendido a la

44 Queda aún por estudiar con mayor profundidad la relación del obispo Las Heras con el alto y bajo cleros. Algunos estudios han resaltado los enfrentamientos ocurridos con el racionero Francisco Carrascón y el maestrescuela José Fernando de Baeza (García-Abásolo, 2015, p. 60).

45 La destitución de los obispos de su dignidad episcopal recaía en el regalismo. Sucedió con el arzobispo Barroeta (Huarcaya, 2018, p. 783), pero es posible que haya sucedido con otros. 
mitra limeña, por lo que supo expresar sus intereses sin remecer las estructuras regalistas.

Un último comentario debe dirigirse al derecho canónico. Se ha mencionado que en la biblioteca de Las Heras se encontraron textos normativos y autores idóneos para la enseñanza de la variante americana del Derecho de la Iglesia. La ofensiva contra la cédula de 1784 tuvo como principal argumento un pasaje de las Sinodales de Caracas, corpus elaborado en suelo sudamericano y reeditado a inicios de la segunda mitad del siglo XVIII. Posiblemente, el plan de vida del obispo Bartolomé María de las Heras pudo ser fortalecer el derecho canónico indiano. Si bien su aporte en esta rama no es comparable a los monumentos jurídicos (Villarroel, Peña Montenegro, Velarde y demás), llevó el proyecto a su aplicación judicial en salas locales e imperiales y fue utilizado como una forma de resistencia al regalismo. Su escrito al rey puede ser visto como un intento de medición del impacto en la propia corte real de ese derecho local. Si bien no tuvo el éxito esperado, no perdió las esperanzas. En 1822, al dejar atrás a su grey peruana y haberse instalado en Madrid, resaltó la necesidad, en un informe al nuncio Santiago Giustiniani, en palabras de Leturia (1935, p. 92), «un derecho canónico acomodado a aquellas tierras y en ellas confeccionado». ${ }^{46}$ En su obispado cusqueño ya lo tenía claro.

46 También citado en Castañeda Delgado (1999, p. 147). En su informe, Las Heras indicó: «La conducta con que se manejan los Canonigos [de Lima] es regular, mas inclinados la mayor parte al gobierno independiente: hay algunos literatos pero siempre propendiendo a iludir en quanto pueden las instituciones de Disciplina, que aseguran ser solo dispuestas para Europa, y de este mismo dictamen son casi todas las Personas que componen el Clero secular y regular; de suerte que desearían tener un Codigo de Canones, que fuese mas mitigado que estubiese echo en America, y si posible por Autoridades eclesiasticas, nacidas, criadas y educadas en su pais, sin duda á fin que pensasen del mismo que ellos opinan» (Leturia, 1935, p. 96). 


\section{REFERENCIAS}

Álvarez de Morales, Antonio (1979). La Ilustración y la Reforma de la Universidad en España del siglo XVIII. Segunda edición aumentada. Madrid: Pegaso.

Benito, José Antonio (2018). «La donación de la biblioteca del arzobispo Bartolomé María de las Heras (1805-1823) al Seminario Santo Toribio en vísperas de la independencia del Perú». Mercurio Peruano, Piura, núm. 531, pp. 72-102.

Brading, David A. (1994). Una Iglesia asediada: el obispado de Michoacán, 17491810. México: Fondo de Cultura Económica.

Burns, Kathryn (2010). Intro the Archive. Durham; Londres: Duke University Press.

Chambers, Sarah (2003). De súbditos a ciudadanos: honor, género y política en Arequipa, 1780-1854. Lima: Pontificia Universidad Católica del Perú, Universidad del Pacífico e Instituto de Estudios Peruanos.

Croix, Teodoro de (1859). Memoria de los virreyes que han gobernado el Perú, durante el tiempo del coloniaje español. Tomo 5: Don Teodoro de Croix. Lima: Librería Imprenta de Felipe Bailly.

De la Puente Brunke, José (2008). «La cultura jurídica en el Perú virreinal». En: Allpanchis, año 29, núm. 71, pp. 45-75.

De la Puente Candamo, José A. (1948). San Martín y el Perú: planteamiento doctrinario. Lima: Lumen.

De la Puente Candamo, José A. (1955). «Sobre la biblioteca de Bartolomé María de las Heras». Mercurio Peruano, año 30, núm. 337, pp. 297-300.

De la Puente Candamo, José A. (2012). «Martínez Compañón en la vida peruana de las postrimerías del siglo XVIII». En: Ignacio Arellano y Carlos Mata Induráin (eds.). El obispo Martinez Compañón: vida y obra de un navarro ilustrado en América. Navarra: Gobierno de Navarra, pp. 191-196. 
Espinavete, Manuel (1795). «Descripción de la provincia de Abancay». Mercurio Peruano, tomo XII, pp. 112-164.

Estenssoro, Juan Carlos (1992). «Modernismo, estética, música y fiesta: élites y cambio de frente a la cultura popular. Perú 1750-1850». En: Enrique Urbano (comp.). Tradición y modernidad en los Andes. Cusco: Centro de Estudios Regionales Andinos «Bartolomé de Las Casas», pp. 181-195.

FARriss, Nancy (1995). La Corona y el clero en el México colonial, 1579-1821. La crisis del privilegio eclesiástico. México: Fondo de Cultura Económica.

FisHer, John (2000). El Perú borbónico, 1750-1824. Lima: Instituto de Estudios Peruanos.

Ganster, Paul Bentley (1986). «Churchmen». En: Louisa Schell Hoberman y Susan Migden (eds.). Cities and Society in Colonial Latin America. Albuquerque: University of New Mexico Press, pp. 137-163.

García-AbÁsolo, Antonio (2015). Itinerario cbileno y peruano de Nicolás Tadeo Gómez. (1755-1839). De sobrecargo del navio Príncipe Carlos a mayordomo de Bartolomé María de las Heras, último arzobispo español de Lima (17851822). Córdoba: Editorial de la Universidad de Córdoba.

GAYOL, Víctor (2007). Laberintos de justicia: procuradores, escribanos y oficiales de la Real Audiencia de México, 1750-1812. Zamora: El Colegio de Michoacán.

Gómez, Cristina y Laurence Coudart (2002). «Bibliotecas de obispos de México colonial en el siglo XVIII». En: Carmen Castañeda (coord.). Del autor al lector. México: Centro de Investigaciones y Estudios Superiores en Antropología Social, pp. 305-321.

GonZÁlez, Francisco (1777). Instrucción para seminarios conciliares y eclesiásticos: obra útil para todo eclesiástico [...], y toda clase de personas que quieran hacer exercicios espirituales, y progresos en la virtud. Madrid: Por D. J. Joachin Ibarra.

Guibovich Pérez, Pedro (2014). Tradición y modernidad. La biblioteca del obispo Pedro José Chávez de la Rosa. Lima: Instituto Riva-Agüero. 
HerA, Alberto de la (1970). «La legislación del siglo XVIII sobre el Patronato Indiano». Anuario de Historia del Derecho Español, tomo 40, pp. 287-312.

Huarcaya, Sergio Miguel (2018). «Disciplinando a los curas: Inmunidad personal del clero y control real en el virreinato del Perú, 1755-1775». Revista de Indias, vol. 77, núm. 274, pp. 757-787.

Leturia, Pedro (1935). La emancipación hispanoamericana en los informes episcopales a Pio VII. Buenos Aires: Imprenta de la Universidad.

Levaggi, Abelardo (1992). Las capellanías en Argentina. Buenos Aires: Universidad de Buenos Aires.

Macera, Pablo (1997). «El tiempo del Obispo Martín Compañón». En: Trujillo del Perú. Baltazar Jaime Martinez de Compañón. Lima: Fundación del Banco Continental, 1997, pp. 13-80.

Matraya y Ricci, Juan Joseph (1978 [1819]). Catálogo cronológico de pragmáticas, cédulas, decretos, órdenes y resoluciones reales (posteriores a la recopilación de 1680). Buenos Aires: Instituto de Investigaciones de Historia del Derecho.

Mendiburu, Manuel de (1880). Diccionario histórico-biográfico del Perú. Parte 1, tomo 4. Lima: Imprenta de J. Francisco Solís.

Morán, Daniel (2012). "AAl César lo qué es del César y a Dios lo que es de Dios". Política y religión en la coyuntura de las guerras de independencia. Perú, 1808-1825». Nuevo Mundo Mundos Nuevos. Publicación electrónica [en línea], fecha de publicación: 29.03.2012. Disponible en: <https://journals.openedition.org/nuevomundo/62864>. Consulta: 27.03.2021.

OTs, José María (1958). Las instituciones del Nuevo Reino de Granada al tiempo de la Independencia. Madrid: Consejo Superior de Investigaciones Científicas.

Peralta Ruiz, Víctor (1999). «Las razones de la fe. La Iglesia y la Ilustración en el Perú, 1750-1800». En: Scarlett O’Phelan (ed.). El Perú en el 
siglo XVIII. La era borbónica. Lima: Pontificia Universidad Católica del Perú, pp. 205-242.

Pietschmann, Horst (1996). Las reformas borbónicas y el sistema de intendencias en Nueva España. México: Fondo de Cultura Económica.

REALEs CÉdulas en FAVOR del Seminario Consillar de SAN GERÓNImo de AREQUIPA... (1808). Lima: Real Casa de Niños Expósitos.

Restrepo, Daniel (1992). Sociedad y religión en Trujillo (Perú), 1780-1790. Vitoria: Servicio de Publicaciones del Gobierno Vasco.

Restrepo, Daniel (2012). «La visita pastoral de don Baltasar Jaime Martínez Compañón a la diócesis de Trujillo (1780-1785)». En: Ignacio Arellano y Carlos Mata Induráin (eds.). El obispo Martínez Compañón: vida y obra de un navarro ilustrado en América. Navarra: Gobierno de Navarra.

Rosas Lauro, Claudia (2009). «Iglesia, evangelización e ilustración en el Perú del Siglo de las Luces». En: Fernando Armas Asín (ed.). La innovación del catolicismo en América. Los procesos de evangelización, siglos XVI-XV III. Lima: Universidad Nacional Mayor de San Marcos.

Salinas, Carlos (2000). «Los textos utilizados en la enseñanza del Derecho Canónico en Chile indiano». Anuario de la Iglesia, Universidad de Navarra, núm. 9, pp. 215-234.

SÁNCHEZ BELLA, Ismael (1986). «Reducción de la jurisdicción eclesiástica en América bajo Carlos III (testamentos y matrimonio)». Revista Chilena de Historia del Derecho, n. 12, pp. 223-262.

Santiago-Otero, Horario, Antonio García y García y José María Soto (1986). «Introducción». En: Sinodo de Santiago de León de Caracas de 1687. Madrid; Salamanca: Instituto Francisco Suárez: VII*LXVI*.

Sinodales de Caracas (1687 [1848]). Constituciones Sinodales del Obispado de Venezuela y Santiago de León de Caracas. Caracas: Reimpresión por Juan Carmen Martel. 
Sinodales de Caracas (1986). Sinodo de Santiago de León de Caracas de 1687. Madrid; Salamanca: Instituto Francisco Suárez.

Soule, Emily Berquist (2014). The bishop's utopia: envisioning improvement in colonial Peru. Philadelphia: University of Pennsylvania Press.

Tau Anzoátegui, Víctor (2005). «El estudio del Derecho indiano provincial y local. Su base documental». En: Renate Pieper y Peer Schmidt (eds.). Latin America and the Atlantic World. Colonia: Böhlau Verlag, pp. 83-96.

Terráneo, Sebastián (2017). «La enseñanza del Derecho Canónico en Indias». Anuario Argentino de Derecho Canónico, vol. 23, tomo 2, pp. 115-144.

Unanue, José Hipólito (1793). Guía política, eclesiástica y militar del Virreynato del Perú. Lima: Imprenta Real de los Huérfanos.

Unanue, José Hipólito (1794). Guía politica, eclesiástica y militar del Virreynato del Perú. Lima: Imprenta Real de los Huérfanos.

Unanue, José Hipólito (1796). Guía política, eclesiástica y militar del Virreynato del Perú. Lima: Imprenta Real de los Huérfanos.

Unanue, José Hipólito (1797). Guía política, eclesiástica y militar del Virreynato del Perú. Lima: Imprenta Real de los Huérfanos.

Uribe, Víctor (1995). «Lawyers and New Granada’s Late Colonial Sate». Journal of Latin American Studies, vol. 27, núm. 3, pp. 517-549.

Uribe, Víctor (1996). «Disputas entre Estado y sociedad sobre la educación de los abogados a finales de la etapa colonial en la Nueva Granada». Historia y Sociedad, Colombia, núm. 3, pp. 33-57.

Valcárcel, Daniel (1953). Libro de Oposiciones de la Universidad de San Antonio del Cusco (Siglo XVIII). Lima: Sociedad Peruana de Historia.

Vargas Ugarte, Rubén (1961). Historia de la Iglesia en el Perú. Tomo 4 (17001800). Burgos: Imprenta de Aldecoa. 
Vargas Ugarte, Rubén (1962). El episcopado en los tiempos de la emancipación sudamericana. Tercera edición. Lima: Librería e Imprenta Gil.

VARgas Ugarte, Rubén (1970). El real convictorio carolino y sus dos luminares. Lima: Carlos Milla Batres.

Villanueva Urteaga, Horacio (1963). La Universidad Nacional de San Antonio Abad del Cuzco. Cusco: Universidad Nacional del Cuzco.

Vizuete Mendoza, J. Carlos (2014). «El arzobispo Francisco Antonio Lorenzana y los libros (Autor, editor y coleccionista)». Anuario Jurídico y Económico Escurialense, núm. 47, pp. 587-614.

YAuzi, Ramón Pedro (2002). «La enseñanza de instituta en la facultad de derecho de la Universidad Nacional de Córdoba. 1791-1870». En: Feliciano Barrios (coord.). Derecho y administración pública en las Indias Hispánicas. Volumen 12, tomo 2. Cuenca: Ediciones de la Universidad de Castilla-La Mancha, pp. 1855-1872.

Zegarra Moretti, Carlos (2011a). Arte, devoción y economía de Ayaviri (17811832): primer libro de fábrica. Cusco: Instituto de Pastoral Andina.

Zegarra Moretti, Carlos (2011b). «La Iglesia de Orurillo». Persona y Cultura, Universidad Católica San Pablo, Arequipa, núm. 9, año 9, pp. 154-163.

Zegarra Moretti, Carlos (2012a). Catálogo del Archivo Histórico de la Prelatura de Sicuani: libros parroquiales. Cusco: Instituto de Pastoral Andina.

Zegarra Moretti, Carlos (2012b). La catedral de Ayaviri en el tiempo. Arequipa: Universidad Católica San Pablo.

Zegarra MoretTi, Carlos (2015). «Normativas sacramentales y las problemáticas en el asentamiento durante el Virreinato del Perú: el caso del sur andino» En: Manuel Salamanca López y Branka Tanodi (coords.). La globalización escrita: usos hispanos en la América colonial. Madrid: Instituto de Estudios Políticos para América Latina y África, pp. 401-441. 


\title{
ANexo: Transcripción de la REAL CÉdUla de 1784 \\ Documento impreso, ubicado en AGI, Cuzco, 24. //Folio recto//
}

\author{
[cruz]
}

\section{EL REY.}

Por quanto han sido varias las Reales decisiones, que por mí, y mis gloriosos Predecesores se han tomado en diversos tiempos, con el fin de evitar competencias entre los Ministros, que exercen mi Real Jurisdiccion, y la Eclesiastica en mis Dominios de la América, sobre a qual de las dos corresponde el conocimiento relativo á la validacion, ó nulidad de los Testamentos, y la faccion de Inventarios respectivos á las Testamentarias de los Clerigos, que instituyen por heredera á sus Almas, ú otras Obras Pias; y conviniendo dar una regla fixa, é invariable, que en lo succesivo no admita intepretaciones, y se consiga el bien del Estado, la utilidad de mis Vasallos, y de la Causa Pública; con atencion a las dudas, que acerca del particular me representó mi Real Audiencia de México en Cartas de dos de Diciembre de mil setecientos sesenta y ocho, y veinte y tres de Noviembre de mil setecientos y ochenta, y á lo que con presencia de ellas, de los antecedentes del asunto, y de lo que expusieron mis Fiscales, me consultó mi Consejo de las Indias en seis de Septiembre del año de mil setecientos ochenta y uno, y treinta de Enero del corriente, he resuelto, que á consecuencia de lo prevenido en la Real Cedula de diez y ocho de Junio de mil seiscientos sesenta y dos, dirigida a mi Real Audiencia de Guadalazara en la Provincia de la Nueva Galicia, y de lo deliberado ultimamente en otra de quince de Noviembre del citado año de mil setecientos ochenta y uno para estos Reynos de Castilla, no se permita en adelante en los de Indias, que los Tribunales Eclesiasticos de ellas tomen conocimiento sobre va- //Folio verso// validacion, ni nulidad de Testamentos, hacer Inventarios, Sequestro, ni Deposito de bienes, que dejaren los Testadores, aunque estos sean Clerigos, y tambien sus herederos, ó hubieren instituido á su Alma, ú Obras Pias; por corresponder á las Justicias Reales la insinuación, y publicacion de los Testamentos, faccion de Inventarios, y tasacion de bienes en todos los casos expresados, con citacion de los herederos instituidos de los Albaceas, ó Tenedores de bienes, si los hubiere nombrados, y demás interesados: que lo mismo se debe observar en los Abintestatos de Clérigos, y en los de Legos, cuyas herencias correspondan 
á Eclesiasticos, pues todos como verdaderos Actores al todo, ó parte de la herencia, que siempre se compone de bienes temporales, y profanos, deben acudir ante las Justicias Reales Ordinarias; además de ser la Testamentificacion Acto Civil, sujeto á las Leyes Reales, sin diferencia de Testadores Eclesiasticos, ó Legos, y un Instrumento público, que tiene en las Leyes prescripta la forma de su otorgamiento: Que estas mismas reglas se guarden, y executen en los Juzgados de Bienes de Difuntos en los casos que correspondan á su peculiar conocimiento: Y que los Fiscales de mis Audiencias cuiden de la defensa de mi Real Jurisdiccion siempre que la vieren perjudicada, usando de los recursos que tiene introducidos la práctica en las mismas Audiencias, y dando cuenta al nominado mi Consejo, quando vieren convenir en el asunto; para cuyo cumplimiento, y execucion se libre la correspondiente Real Cedula, sin embargo de qualesquiera anteriores Reales Ordenes, usos, costumbre, ó práctica, que se hubiere observado en contrario, y del Auto acordado inserto en el Ti. 13. Lib. 4. de las Synodales del Obispado de Caracas. Por tanto por la presente ordeno, y mando á mis Virreyes, Presidentes, Regentes, Audiencias, Fiscales de ellas, Oidores, Jueces de Bienes de Difuntos, Gobernadores, y demas Justicias de aquellos mis Reynos, é Islas, guarden, cumplan, y executen, y hagan guardar, cumplir, y executar esta mi Real resolucion, puntual, y efectivamente, segun, y en la forma que va referido, sin permitir, //Folio recto// ni consentir, que ahora, ni en tiempo alguno se contravenga á ella, en todo, ni en parte, por ser mi voluntad. Fecha en Aranjuez á veinte y siete de Abril de mil setecientos ochenta y quatro. $=$ Yo el Rey= Por mandado del Rey nro ${ }^{\circ} . S^{\text {or }} .=\mathrm{d}^{\mathrm{n}}$ Miguel de $\mathrm{S}^{\mathrm{n}}$. Martin Cueto=

Para que los Tribunales Eclesiasticos de Indias no se introduzcan en el conocimiento de las Testamentarias, Abintestatos, ni sus incidencias, y lo que sobre esto debe observarse.

//Folio verso//

$$
\text { [cruz] }
$$

S.M. en Aranjuez a 27, de Abril de 1784,,

Sobre el concim ${ }^{\text {to }}$. de las Testamentarias, y Abintestatos. 


\section{Agradecimientos}

Quiero dejar constancia de mi sincero agradecimiento al Dr. Renzo Honores por la invitación a participar en este número temático y, más aún, por las recomendaciones bibliográficas que han nutrido este estudio.

Fecha de recepción: 30 de noviembre de 2020.

Fecha de evaluación: 1 de marzo de 2021.

Fecha de aceptación: 29 de abril de 2021.

Fecha de publicación: 30 de junio de 2021.

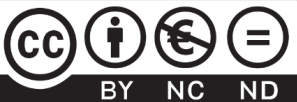

